\title{
O resgate da centralidade cristológica no Culto: uma análise teológico-prática das igrejas batistas litorâneas fluminenses
}

\author{
Orientador: Abimar Oliveira de Moaraes
}

Doutorando: Elildes Junio Macharete Fonseca

Área de Concentração: Teologia Sistemático-Pastoral

Linha de Pesquisa: Fé e Cultura

A Igreja Batista possui características singulares, como o princípio da autonomia da igreja local. Cada congregação é uma unidade autônoma, ligada às demais pelo vínculo denominacional, através da Convenção Batista Brasileira, Convenções estaduais e Associações regionais. A autonomia da igreja local favorece a diversidade cúltica, pois cada igreja é livre para adotar o seu estilo. Embora seja um belo e essencial princípio batista, a autonomia favorece a pluralidade litúrgica, muitas vezes com a daninha influência de elementos que comprometem a centralidade cristológica no culto, como a liturgia neopentecostal, as literaturas de mercado e a ausência de reflexão teológica. O conhecimento da Teologia do Culto Cristão, mesmo em tradições diferentes, que até mesmo antecederam à tradição batista, é um caminho necessário para o resgate da centralidade cristológica no culto. Esse resgate das riquezas da tradição cúltica em diálogo com a Igreja Batista permitirá uma leitura justa e coerente da denominação batista, oferecendo respostas para os possíveis problemas de esvaziamento da centralidade cristologica no culto. Uma vez que o universo batista brasileiro, ou até mesmo fluminense, é muito amplo, para fins de análise da realidade litúrgica da Igreja Batista, com dados advindos de momento empírico na pesquisa, fez-se um corte geográfico na região litorânea fluminense, focando a pesquisa exclusivamente com as igrejas vinculadas à Associação Batista Litorânea Fluminense. A pesquisa, que alcançou membros de aproximadamente $90 \%$ das referidas igrejas, além de pastores e seminaristas (estudantes de Teologia), revelou realidades que confirmam a necessidade da proposta de resgate da centralidade cristológica no culto, sendo fonte de pesquisa e reflexão para a Igreja Batista. Embora a Igreja Batista não adote nenhum calendário ou manual litúrgico, mesmo diante do princípio de autono- 
mia de cada congregação local, há uma "fé batista", há uma tradição que perdura gerações. Seria um prejuízo à Igreja Batista e seu culto "virar as costas" ao assunto. $\mathrm{O}$ objetivo não é uniformizar o culto batista, até mesmo porque isso feriria frontalmente o "jeito batista de ser". Pelo contrário, o objetivo é oferecer respostas, é dar subsídio para uma reflexão teológica consistente, capaz de fomentar valores imprescindíveis para o culto verdadeiramente cristológico e expurgar influências negativas.

Palavras-chave: Culto. Liturgia. Igreja Batista. 